\title{
Angiotensin-(1-7) counteracts the transforming effects triggered by angiotensin II in breast cancer cells
}

\author{
Nadia Cambados ${ }^{1}$, Thomas Walther ${ }^{2,4,5}$, Karen Nahmod ${ }^{6}$, Johanna M. Tocci ${ }^{1}$, Natalia \\ Rubinstein $^{1,7}$, Ilka Böhme ${ }^{2,3}$, Marina Simian ${ }^{8}$, Rocío Sampayo ${ }^{8}$, Melisa Del Valle \\ Suberbordes $^{1}$, Edith C. Kordon ${ }^{1,9}$ and Carolina Schere-Levy ${ }^{1}$ \\ ${ }^{1}$ Instituto de Fisiología, Biología Molecular y Neurociencias, Facultad de Ciencias Exactas y Naturales, Universidad de Buenos \\ Aires, Buenos Aires, Argentina \\ ${ }^{2}$ Department of Obstetrics, University of Leipzig, Leipzig, Germany \\ ${ }^{3}$ Department of Pediatric Surgery, University of Leipzig, Leipzig, Germany \\ ${ }^{4}$ Department Pharmacology and Therapeutics, School of Medicine and School of Pharmacy, University College Cork, Cork, Ireland \\ ${ }^{5}$ Institute of Medical Biochemistry and Molecular Biology, University Medicine Greifswald, Greifswald, Germany \\ ${ }^{6}$ Department of Pediatrics, Immunology, Allergy and Rheumatology, Center for Human Immunobiology, Texas Children's \\ Hospital, Houston, Texas, USA \\ ${ }^{7}$ Departamento de Fisiología, Biología Molecular y Celular, Facultad de Ciencias Exactas y Naturales, Universidad de Buenos \\ Aires, Buenos Aires, Argentina \\ ${ }^{8}$ Instituto de Nanosistemas, Universidad Nacional de San Martín, Buenos Aires, Argentina \\ ${ }^{9}$ Departmento de Química Biológica, Facultad de Ciencias Exactas y Naturales, Universidad de Buenos Aires, Buenos Aires, Argentina \\ Correspondence to: Carolina Schere-Levy, email: carolinaschere@gmail.com \\ Keywords: AKT, angiotensin II, angiotensin-(1-7), breast cancer cells, epithelial-mesenchymal transition \\ Received: November 04, $2016 \quad$ Accepted: June 02, $2017 \quad$ Published: July 17, 2017 \\ Copyright: Cambados et al. This is an open-access article distributed under the terms of the Creative Commons Attribution License 3.0 \\ (CC BY 3.0), which permits unrestricted use, distribution, and reproduction in any medium, provided the original author and source are \\ credited.
}

\section{ABSTRACT}

Angiotensin (Ang) II, the main effector peptide of the renin-angiotensin system, has been implicated in multiple aspects of cancer progression such as proliferation, migration, invasion, angiogenesis and metastasis. Ang-(1-7), is a biologically active heptapeptide, generated predominantly from AngII by the enzymatic activity of angiotensin converting enzyme 2. Previous studies have shown that Ang-(1-7) counterbalances AngII actions in different pathophysiological settings. In this study, we have analysed the impact of Ang(1-7) on AngII-induced pro-tumorigenic features on normal murine mammary epithelial cells NMuMG and breast cancer cells MDA-MB-231. AngII stimulated the activation of the survival factor AKT in NMuMG cells mainly through the AT1 receptor. This PI3K/AKT pathway activation also promoted epithelial-mesenchymal transition (EMT). Concomitant treatment of NMuMG cells with AngII and Ang-(1-7) completely abolished EMT features induced by AngII. Furthermore, Ang-(1-7) abrogated AngII induced migration and invasion of the MDA-MB-231 cells as well as pro-angiogenic events such as the stimulation of MMP-9 activity and VEGF expression. Together, these results demonstrate for the first time that Ang-(1-7) counteracts tumor aggressive signals stimulated by AngII in breast cancer cells emerging the peptide as a potential therapy to prevent breast cancer progression.

\section{INTRODUCTION}

Independently of its role in homeostasis of cardiovascular and renal systems, angiotensin II (AngII) acts as a true cytokine modulating in a paracrine and autocrine manner multiple biological processes like tissue regeneration, cellular proliferation, growth factor release, and inflammation [1-3]. AngII acts through two different $\mathrm{G}$ protein-coupled receptors, AngII type 1 receptor (AT1) and AngII type 2 receptor (AT2), which have distinctive pharmacological and signal transducing 
characteristics [4]. AT1 receptor mediates most of the AngII actions, thus representing a critical pharmacological target in the treatment of several cardiovascular disorders $[5,6]$.

In addition to AngII, the main effector peptide of the system, other peptides like AngIII [Ang-(2-8)], AngIV [Ang-(3-8)] and Ang-(1-7) have been identified as biologically active mediators of the renin-angiotensin system (RAS). In contrast to Ang metabolites with truncation on the N-terminus (AngIII and AngIV), which still show similar detrimental effects as Ang II due to stimulation of the AT1 receptor, the heptapeptide Ang(1-7) mainly generated by the monocarboxypeptidase angiotensin converting enzyme 2 (ACE 2), attracted special attention over the last two decades for showing the critical ability to counteract many actions of AngII in different pathophysiological settings [7-11]. Consequently, Ang-(1-7) has shown potent vasodilative, antiproliferative, antiangiogenic and antithrombotic properties [12-14]. We have previously identified the G protein-coupled receptor Mas, encoded by the Mas protooncogene, as a receptor being associated with Ang-(1-7)mediated signaling [15]. Tissue RAS, where angiotensin peptides are locally produced in different organs have received special attention during the last decades [16]. Expression of RAS components such as angiotensinogen, renin, angiotensin converting enzyme, and angiotensin receptors in normal and transformed mammary ducts has been independently demonstrated by different groups [1720]. Moreover, we described a substantial contribution of the RAS in the postlactational regression phase, where AT1 receptor signaling together with other local factors mediates apoptosis and tissue remodeling in the mammary gland [20].

It has been demonstrated that AngII plays a critical role in breast cancer development by stimulating cell proliferation of breast cancer cells and tumor angiogenesis [21-23], and modulating tumor cell migration and invasion [24-28]. In addition, it has been recently demonstrated that overexpression of AT1 receptor in breast cancer cells, induces epithelial-mesenchymal transition (EMT) and promotes tumor growth and angiogenesis [29]. EMT is a highly conserved biological process characterized by the conversion of polarized, immotile epithelial cells into mesenchymal cells with a motile phenotype. It has been shown that EMT is involved in promoting cancer cell invasion, metastasis and chemoresistance [30]. Moreover, AT1 blockers (ARBs) or ACE inhibitors have efficiently reduced tumor growth, angiogenesis, and metastasis in experimental mouse models [31-34]. However, whether other angiotensin peptides can modulate AngII protumorigenic actions in mammary cells remain largely unknown. In the present work, we studied the impact of Ang-(1-7) on AngII-induced pro-oncogenic features in non-tumorigenic epithelial cells and breast cancer cells.

Here, we describe that AngII induced EMT in normal mammary epithelial cells is completely abolished by Ang-(1-7). Since migration and invasion features triggered by AngII in breast cancer cells are also blunted by the heptapeptide, it identifies Ang-(1-7) as a potential preventive therapy for breast cancer metastasis.

\section{RESULTS}

\section{Ang-(1-7) inhibits ERK1/2 and AKT activation induced by AngII}

Alterations on PI3K/AKT pathway have been shown to play a significant role in the development, progression, and metastatic spread of breast cancer cells. It has been shown that AngII induces AKT activation in several cell types [27, 28, 35].

In order to study the effects of AngII and Ang-(1-7) on AKT phosphorylation, the non-tumorigenic mammary epithelial cell line NMuMG was stimulated with AngII or Ang-(1-7) at $10^{-7} \mathrm{M}$ for the indicated time (Figure 1A). AngII induced AKT phosphorylation that peaked at $1 \mathrm{~min}$ and declined to normal at $30 \mathrm{~min}$. In contrast, Ang-(1-7) induced a maximal AKT phosphorylation at 15 min (Figure 1A). When both peptides were added together, maximal phosphorylation of AKT was observed at 15 minutes, resembling the pattern of activation induced by Ang-(1-7) and disappearing the peack observed at 1 min with AngII alone. We next determined ERK1/2 phosphorylation under angiotensin stimulation (Figure 1B). While AngII strongly induced ERK1/2 activation with maximal activation at $5 \mathrm{~min}$, a weaker, but significant signal was observed after Ang-(1-7) stimulation. Notably, this signal occurred earlier than the peak in AKT phosphorylation. When cells were simultaneously stimulated with both peptides, Ang-(1-7) significantly inhibited AngII induced ERK1/2 activation.

With the aim of identifying the receptor involved in AngII and Ang-(1-7) signal transduction, AKT or EKR1/2 phosphorylation were determined in the presence of specific pharmacological receptors blockers targeting the RAS (Figure 2). AngII alone significantly induced AKT and ERK1/2 activation compared to control levels after 1min or 5 min of incubation, respectively (Figure $2 \mathrm{~A} \& 2 \mathrm{C}$ ). In the presence of AT2 receptor blocker PD123319, AngII maintained significant levels of both AKT and ERK1/2 activation with only a mild blockade observed. Both AKT and EKR $1 / 2$ activation induced by AngII were significantly blocked by an AT1 receptor blocker, Irbesartan, which restored values to control levels, suggesting that AngII exerts its function mainly through the AT1 receptor. In the presence of Ang-(1-7), AKT and ERK1/2 activation were induced (Figure 2A\&2C). Similar levels of AKT and ERK1/2 activation induced by Ang-(1-7) were maintained in the presence of PD123319 or Irbesartan (data not shown) or the Ang-(1-7) antagonist D-Pro (D-Pro -Ang-(1-7)), which has been identified as a Mas and $\mathrm{MrgD}$ receptor blocker in in vitro experiments $[36,37]$ (Figure 2B\&2D). In contrast, treatment with the Mas receptor blocker, A779, significantly 
blocked AKT and EKR1/2 phosphorylation induced by Ang-(1-7) to control levels (Figure 2B\&2D). Notably, ERK1/2 phosphorylation, but not AKT phosphorylation, was significantly induced with PD123319 and D-Pro alone. Thus, we cannot conclude on PD and D-Pro effects of ERK1/2 activation since the compounds stimulates ERK1/2 phosphorylation almost equally effective as Ang-(1-7) discarding significant blocking effects observed when Ang(1-7) and D-Pro were added together (Figure 2D).

\section{Ang-(1-7) abolishes AngII induced epithelial-to- mesenchymal transition}

Reports strongly indicate that both invasion and metastasis may be dependent on the acquisition of epithelial-to-mesenchymal transition (EMT) features by primary cancer cells [38]. During EMT, cells lose their epithelial characteristics such as cell polarity and cell-cell contact, usually measured as a decrease in E-cadherin expression, and acquires mesenchymal features such as motility and a spindle-shaped phenotype [39, 40]. These attributes increase cell motility, resulting in the release of cells from the parental epithelial tissue site and gain the ability to reconstitute metastatic colonies at distant sites. A small subpopulation of cancer cells acquires cancer stem-like cell (CSCs) traits, exhibiting mesenchymal cell features associated with increase of EMT-related markers such us N-cadherin, Vimentin, $\alpha$-SMA (anti alfa-smooth muscle actin), fibronectin or Snail [41]. The non-tumorigenic mammary epithelial
A

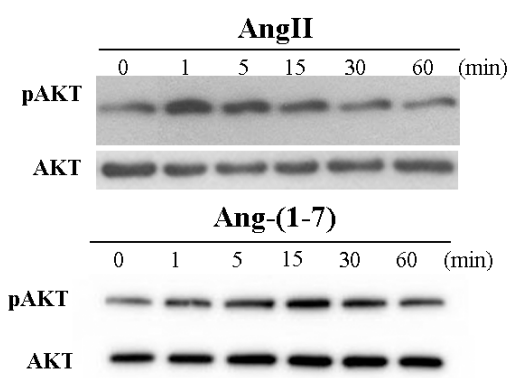

AKT

$$
\begin{array}{llllll}
\multicolumn{5}{c}{\text { AngII }+} & \text { Ang-(1-7) } \\
\hline 0 & 1 & 5 & 15 & 30 & 60 \\
\text { (min) }
\end{array}
$$

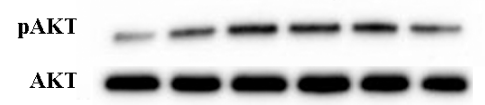

B
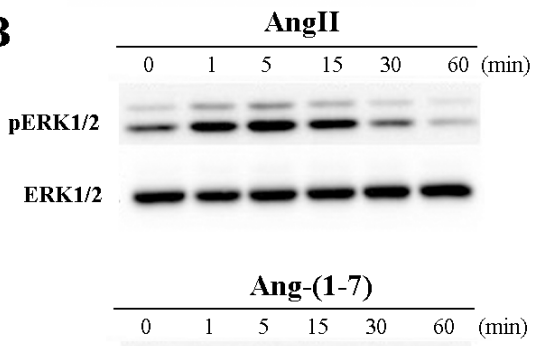

pERK1/2

ERK1/2

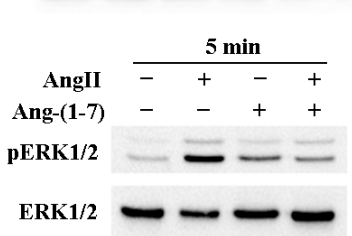

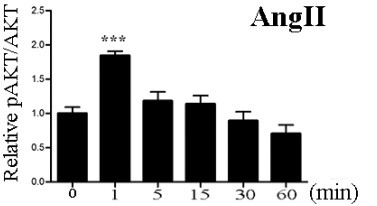
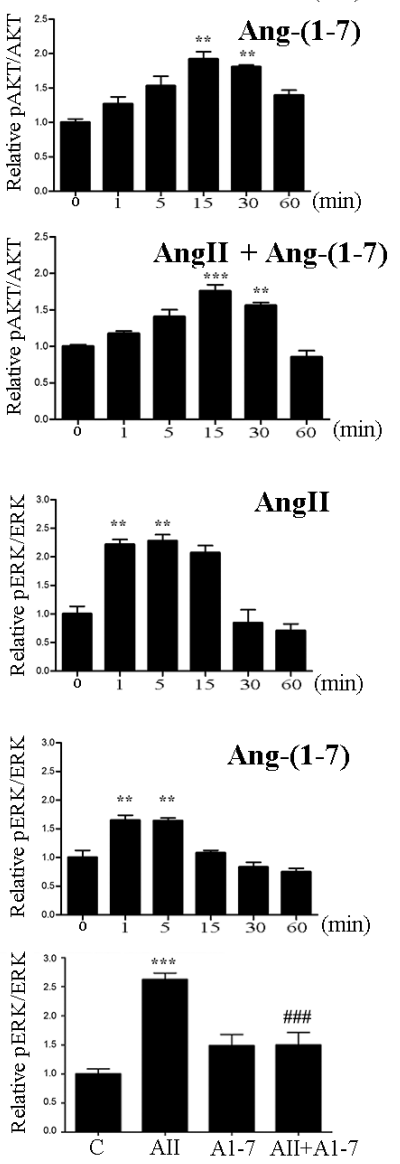

Figure 1: Ang-(1-7) prevents AngII-induced AKT and ERK1/2 phosphorylation in the non-tumorigenic mammary cell line NMuMG. Left panels show representative Western blots; right panels show quantification by densitometry. Effect of AngII $\left(10^{-7} \mathrm{M}\right)$ and/or Ang-(1-7) (10 $\left.{ }^{-7} \mathrm{M}\right)$ on AKT (A) and ERK1/2 (B) phosphorylation for the indicated time. WB analyses were performed using phosphospecific antibodies against ERK1/2 and AKT. The same samples were blotted with antibodies to account for total kinase expression (lower panel for each kinase). $\mathrm{N}$ of 3 independent experiments; Values shown in bar represent mean $\pm \mathrm{SEM}, * * \mathrm{P}<0.01, * * * \mathrm{P}<0.001$ vs untreated cells, $\mathrm{P}<0.001$ vs AngII. 
cell line NMuMG is a generally accepted cell model to study EMT phenomena [42]. We describe here for the first time that treatment of NMuMG cells with AngII for 3 days resulted in a transition from an epithelial to a mesenchymal phenotype (Figure 3A). In the presence of AngII, the expression of epithelial markers such as E-cadherin was inhibited ( 0.52 fold $v s$ control) while mesenchymal markers such as fibronectin, $\mathrm{N}$-cadherin and $\alpha$-SMA were enhanced (fibronectin 2.49 fold, $\mathrm{N}$-cadherin 1.86 fold, and $\alpha$-SMA 2.0 fold) (Figure $3 \mathrm{~A})$. In contrast, Ang-(1-7) was unable to induce any changes on the expression of EMT markers. Importantly, when both peptides were simultaneously added to the cell culture, Ang-(1-7) abolished AngII-induced EMT changes in E-cadherin and fibronectin and partially blocked the changes in N-cadherin and $\alpha$-SMA (Figure 3A). Similar results and morphological changes were observed when immunofluorescence was performed to evaluate EMT markers on these cells (Figure 3B), with Ang-(1-7) preventing not only suppression of E-cadherin but also upregulation of fibronectin stimulated by AngII.

\section{AngII induces EMT and migration through AKT activation}

We further examined whether AKT activation is involved in AngII-induced EMT in mammary epithelial cells. We found that in the presence of the an AKT1/2 kinase inhibitor, A6730, the expression of the epithelial and mesenchymal EMT biomarkers were almost restored to control levels, with highest efficacy on E-cadherin and fibronectin expression (Figure 4). These results suggest that AKT phosphorylation is at least in part necessary for AngII-induced EMT.

\section{Ang-(1-7) prevents AngII-induced metastatic features on breast cancer cells}

We next evaluated the effects of AngII and Ang(1-7) on cell migration and invasion in two potentially metastatic mammary cancer cells lines: MDA-MB-231 (human) and LM3 (mouse). We found that Ang-(1-7) completely blocked AngII-induced tumor cell migration
A

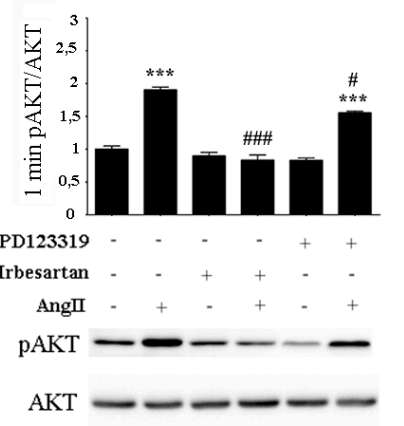

C

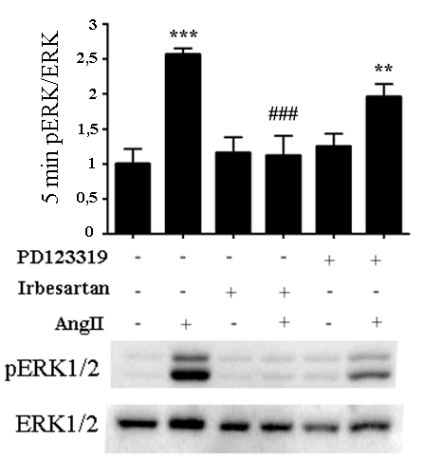

B

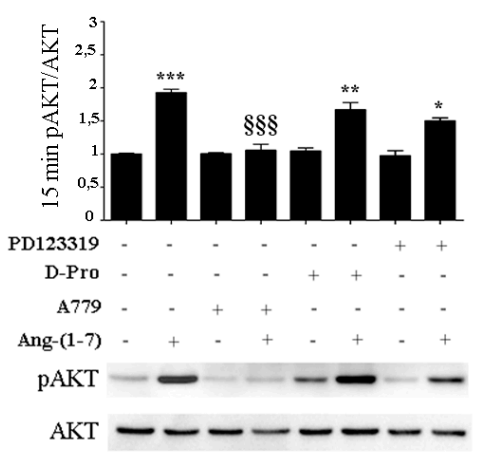

D

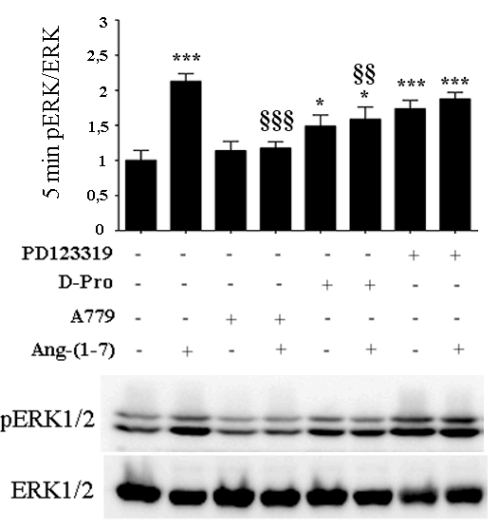

Figure 2: AngII induces ERK1/2 and AKT activation through AT1 receptor while Ang-(1-7) acts through the Mas receptor. Western Blot analyses from the non-tumorigenic mammary cell line NMuMG were performed for p-AKT and AKT (A-B) and p-ERK1/2 and ERK1/2 (C-D). Cells were pre-incubated for 5 min with Irbesartan $\left(10^{-6} \mathrm{M}\right)$, PD123319 (10 $\left.0^{-6} \mathrm{M}\right)$, A779 (10-6 M), or D-Pro $\left(10^{-6} \mathrm{M}\right)$, and then stimulated with AngII $\left(10^{-7} \mathrm{M}\right)(\mathrm{A}-\mathrm{C})$ or $(\mathrm{B}-\mathrm{D})$ Ang-(1-7) $\left(10^{-7} \mathrm{M}\right)$ for the indicated time. Blots show representative Western blots. $\mathrm{N}$ of 3 independent experiments; values shown in bar represent mean $\pm \mathrm{SEM}$ quantified by densitometry and relative to control-untreated cells. ${ }^{*} \mathrm{P}<0.05,{ }^{*} * \mathrm{P}<0.01,{ }^{* * *} \mathrm{P}<0.001$ vs untreated control cells; ${ }^{\#} \mathrm{P}<0.05,{ }^{\#} \mathrm{P}<0.01,{ }^{\# \#} \mathrm{P}<0.001$ vs AngII or ${ }^{\delta s} \mathrm{P}<0.01$, ss $\mathrm{P}<0.001$ vs Ang-(1-7) treated cells. 

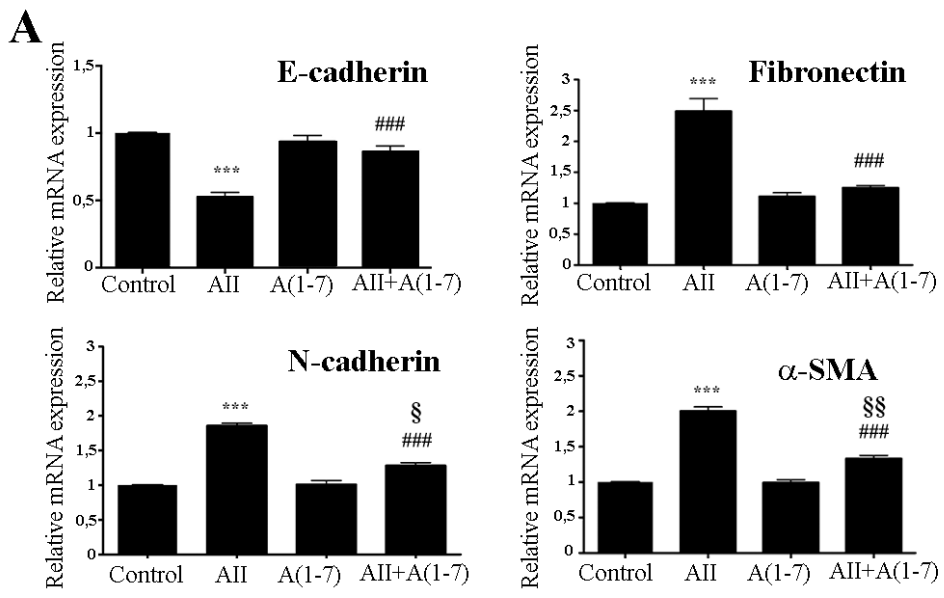

\section{B}
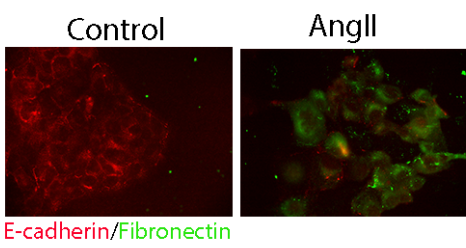

Ang-(1-7)

Angll+Ang-(1-7)
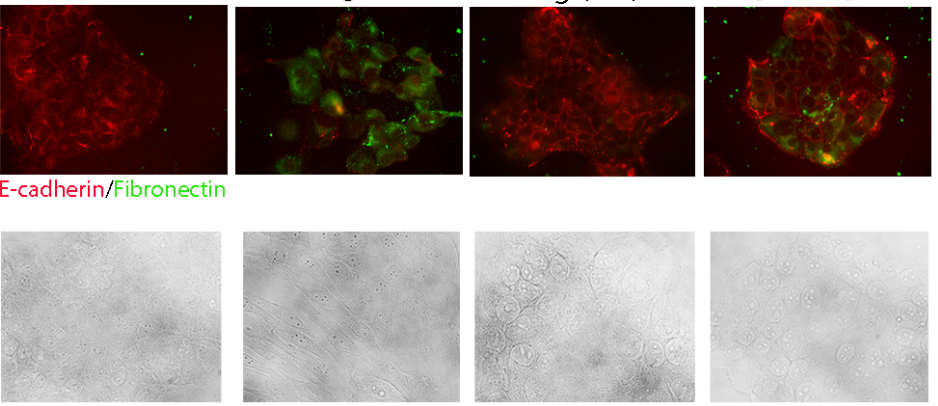

Figure 3: Ang-(1-7) abolish AngII-induced EMT in the non-tumorigenic mammary cell line NMuMG. (A) Cells were treated with AngII $\left(10^{-7} \mathrm{M}\right)$ and/or Ang- $(1-7)\left(10^{-7} \mathrm{M}\right)$ for 3 days. The mRNA levels of E-cadherin, fibronectin, N-cadherin and a-SMA were determined by qRT-PCR. mRNA levels have been normalized to GAPDH and relative to control. Bars indicate means \pm SEM, $\mathrm{n} \geq$

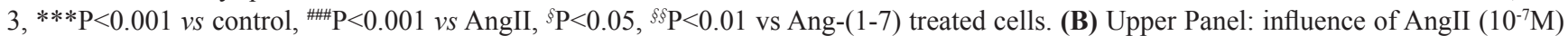
and/or Ang-(1-7) $\left(10^{-7} \mathrm{M}\right)$ on E-cadherin and fibronectin expression and subcellular localization after 3 days of treatments. NMuMG cells were immunostained for E-Cadherin (red) or fibronectin (green). Images are shown at $\times 400$ magnification. Lower Panel: Bright fields of morphological changes induced by AngII $\left(10^{-7} \mathrm{M}\right)$ on NMuMG treated cells during EMT process.
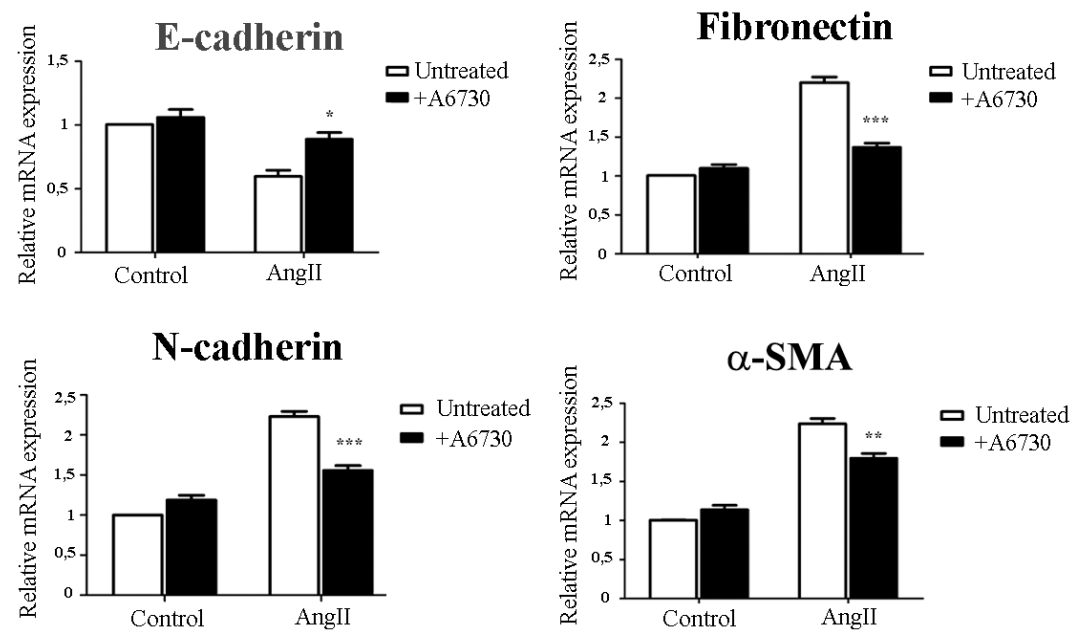

Figure 4: AngII induces EMT and through AKT activation. NMuMG cells were treated for 3 days with AngII (10 $\left.{ }^{-7} \mathrm{M}\right)$ in the presence or absence of an AKT inhibitor A6730 (1uM). The mRNA levels of E-Cadherin, Fibronectin, N-cadherin and a-SMA were determined by qRT-PCR. mRNA levels have been normalized to GPDH and relative to control. Bars indicate means $\pm \mathrm{SEM}, \mathrm{n} \geq 3,{ }^{*} P<0.05, * * P<0.01, * * * \mathrm{P}<0.001 v s$ untreated cells. 
either performed on wound healing or in transwell assays (Figure 5A-5B). The migration observed was not due to proliferation, since neither AngII $\left(10^{-7} \mathrm{M}\right)$ nor Ang-(1-7) $\left(10^{-7} \mathrm{M}\right)$ did induce cell proliferation after $24 \mathrm{~h}$ of treatment (Figure 5C).

Similar results were obtained in invasion assays using filters coated with matrigel that mimics the extracellular matrix. As shown in Figure 6A, Ang-(1-7) also abolished the invasion induced by AngII on breast cancer cells.
Vascular endothelial growth factor (VEGF) has been identified as a potent cytokine involved in tumor angiogenesis and metastasis formation [43]. When breast cancer cells were stimulated with AngII, the expression of VEGF was increased (2.39 fold). Interestingly, cotreatment of Ang-(1-7) with AngII completely abolished this increase in VEGF mRNA levels in breast cancer cells (Figure 6B). Similar to Ang-(1-7), the treatment with an anti-VEGF antibody (bevacizumab) abolished

A

MDA-MB231 Cells
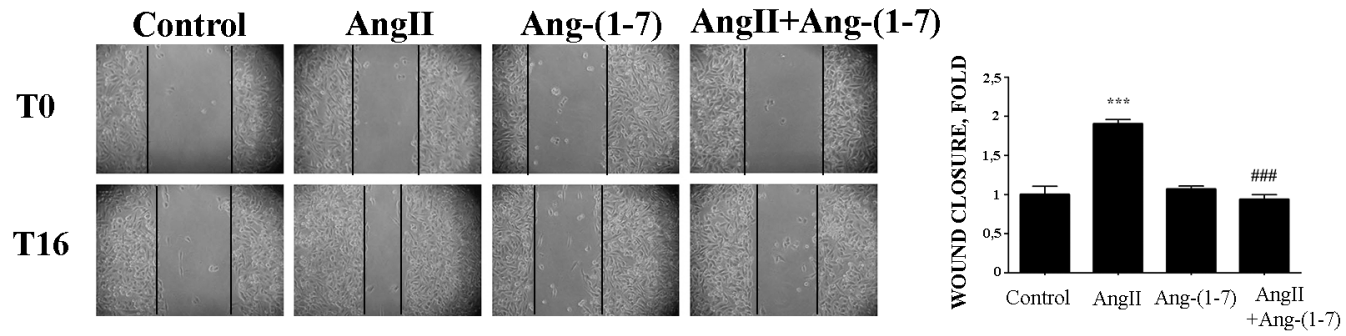

\section{LM3 Cells}

T0
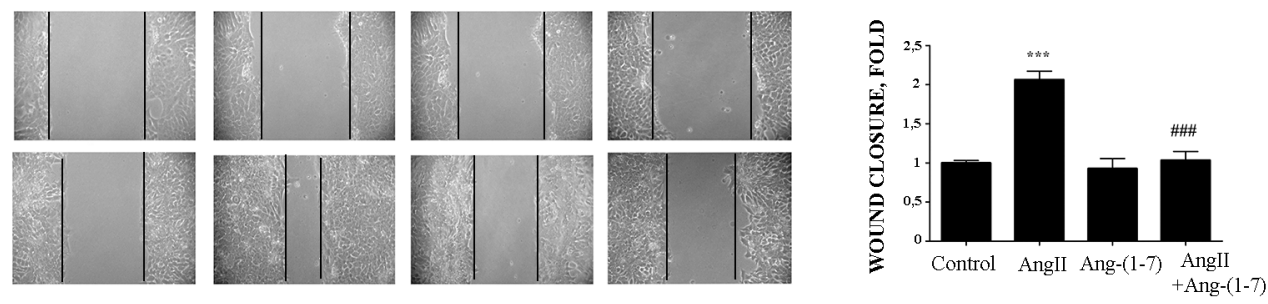

B

\section{MDA-MB231 Cells}
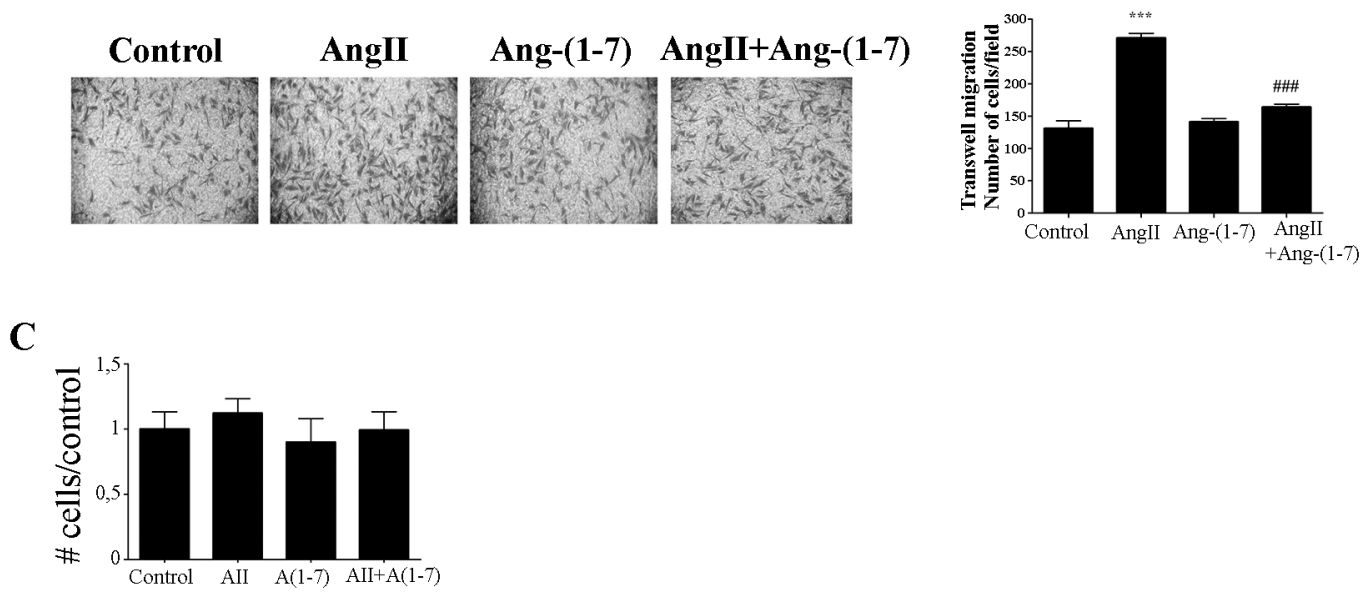

Figure 5: Ang-(1-7) blockes AngII induced tumor cell migration. (A) Wound healing assay on MDA-MB231 or LM3 cells. Wounds were registered by phase contrast microscopy immediately after scratching (T0) and after $16 \mathrm{~h}$ in serum-free medium (T16) treated with AngII $\left(10^{-7} \mathrm{M}\right)$ and/or Ang- $(1-7)\left(10^{-7} \mathrm{M}\right)$. Bars show results from 3 independent experiments performed and expressed as fold increase of wound closure at time $16 \mathrm{hrs}$ (T16) compared to control (untreated cells). Representative pictures of wounds at T0 and T16, magnification, 100x. Bars indicate means \pm SEM, $* * * P<0.001$ vs control, ${ }^{\#} P<0.001$ vs AngII. (B) Transwell cell migration assayed with MDA-MB23 1 cells in serum-free media across $8 \mathrm{~mm}$-pore filters coated with type I collagen. The cells that migrated to the lower portion of the chamber, were fixed and stained with cristal violet, and five fields per well were counted. Bars indicate number of migrated cells, means $\pm \mathrm{SEM}, \mathrm{n} \geq 3 * * * P<0.001$ vs control or ${ }^{\# \#} \mathrm{P}<0.001$ vs AngII. (C) AngII $\left(10^{-7} \mathrm{M}\right)$ and Ang-(1-7) $\left(10^{-7} \mathrm{M}\right)$ had no effect on cell proliferation measured over $24 \mathrm{~h}$ by cell counting and MTS assay in MDA-MB231 cells. 
AngII -induced cell migration of MDA-MB-231 cells (Figure 6D).

Tumor cells are believed to utilize the matrix metalloproteases degrading capability to spread to distant sites. Previous studies have extensively documented AngII-mediated activation of MMP-9 in several cell types [44]. In agreement with those studies, we have previously demonstrated that AngII, through AT1 receptor, activates MMP-9 activity during mammary gland involution [20]. As depicted in Figure 6B-6C, Ang-(1-7) abolished MMP-9 expression and activity triggered by AngII on breast cancer cell line MDA-MB231.

\section{DISCUSSION}

Our study shows that Ang-(1-7) has the ability to counteract AngII-induced metastatic features in breast cancer cells. Pro-metastatic effects of AngII in various experimental models in vivo and in vitro have been well documented and attributed to its actions on the host
A

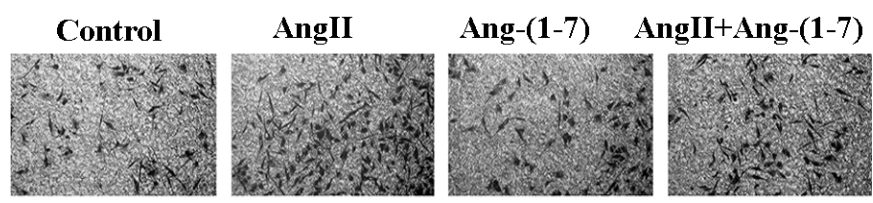

B
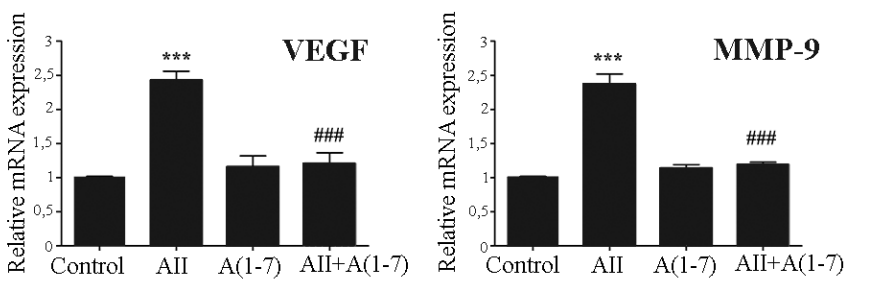

D MDA-MB231 Cells

T0

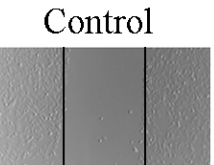

T16

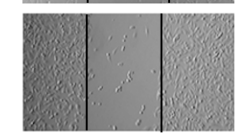

AngII

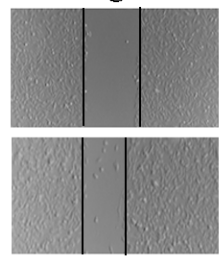

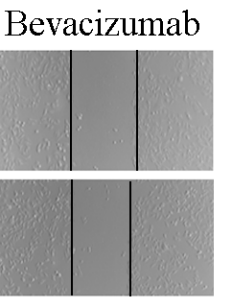

Bevacizumab

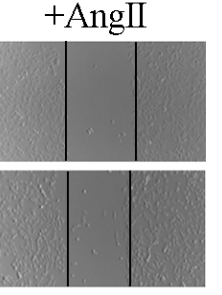

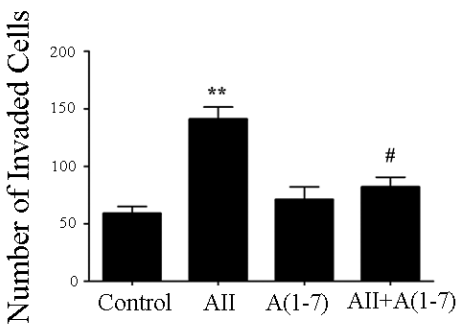

C
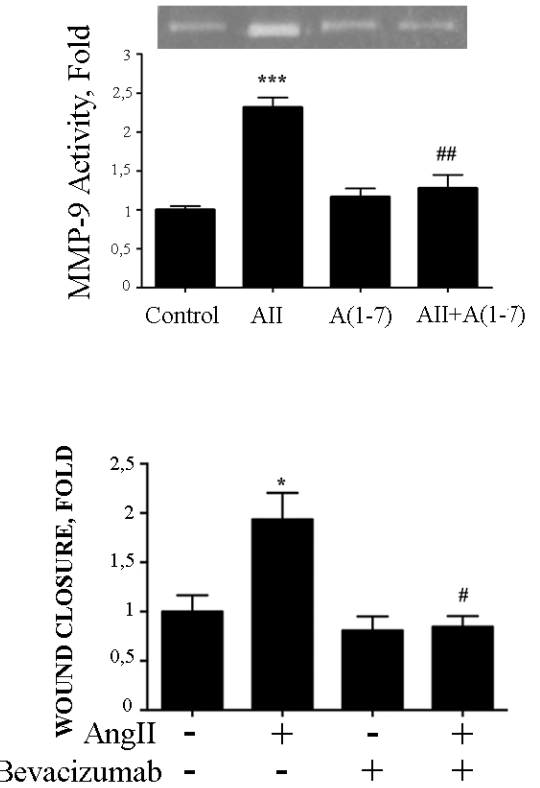

Figure 6: Ang-(1-7) abolishes AngII-induced breast cancer cell invasion, MMP-9 activity and VEGF and MMP-9 expression. (A) Transwell cell invasion assayed of MDA-MB231 cell in serum-free media across 8 mm-pore filters coated with matrigel. Cells that migrated to the lower portion of the chamber were fixed and stained with cristal violet, and five fields per well were counted. Bars indicate number of invaded cells, means \pm SEM, $\mathrm{n} \geq 3, * * P<0.01$ vs control or ${ }^{\#} P<0.05$ vs AngII. (B) VEGF and MMP-9 mRNA expression levels were determined by qRT-PCR on MDA-MB231 cells treated with AngII (10-7 M) and/or Ang- $(1-7)\left(10^{-7} \mathrm{M}\right)$ for 24 h. mRNA levels have been normalized to GAPDH and relative to control. Bars indicate means $\pm \mathrm{SEM}, \mathrm{n} \geq 3 * * * P<0.001$ vs control or ${ }^{\# \#} \mathrm{P}$ $<0.001 v s$ AngII. (C) Gelatin-based zymography analysis of MMP-xs9 activity in conditioned medium of MDA-MB231 cells treated as in B. Image shown is one representative of 3 independent experiments (Upper panel). For quantification (ImageJ software), results were normalized to the quantity of proteins in cell lysate and expressed relative to control (lower panel). Bars indicate means \pm SEM, $\mathrm{n} \geq 3$, $* * * P<0.001$ vs control or ${ }^{\# \#} P<0.01$ vs AngII. (D) Wound healing assay on MDA-MB231 cells. Wounds were registered by phase contrast microscopy immediately after scratching (T0) and after $16 \mathrm{~h}$ in serum-free medium (T16) treated with AngII (10 $\left.0^{-7} \mathrm{M}\right)$ and/or bevacizumab $(100 \mathrm{ug} / \mathrm{ml})$. Bars show results from 3 independent experiments performed and expressed as fold increase of wound closure at time $16 \mathrm{hrs}$ (T16) compared to control (untreated cells). Representative pictures of wounds at T0 and T16, magnification 100x. Bars indicate means \pm SEM, ${ }^{*} P<0.05$ vs control, ${ }^{\#} P<0.05$ vs AngII. 
microenvironment [31, 32, 45, 46]. Our study confirms the reported stimulating effects of AngII on breast cancer cell migration, invasion and activation of pro-metastatic factors such as MMP-9 and VEGF, supporting the notion that AngII can promote tumor cell growth and metastasis progression. We show here for the first time that Ang(1-7), acting mainly through the Mas receptor, abolishes AngII-induced migration, invasion, VEGF expression, and MMP-9 activity in breast cancer cells. Moreover, we found that Ang-(1-7) completely blockes AngIIinduced EMT, which is an essential step occurring during metastasis progression.

Dysregulation of the PI3K/AKT pathway occurs in more than $70 \%$ of breast cancers [47]. PI3K can be activated by RTKs or downstream of GPCRs through direct interaction with heterotrimeric $G$ protein subunits [48]. In the specific setting of post-lactational regression phase, we have previously observed AKT and ERK1/2 pathway activation in the presence of the AT1 receptor blocker Losartan in an in vivo model [20]. Previous findings support a dose-dependent effect of AngII on cancer cell proliferation and cell survival through the PI3K/Akt pathway [27, 28, 44]. In addition, AngIImediated cell migration in choriocarcinoma cells can be abolished by a selective AT1 antagonist and a PI3K inhibitor [49]. In MDA-MB-231 cells, AngII induced AKT activation, and pretreatment of cells with PI3K or AKT inhibitors significantly reduced AngII-mediated cell migration and MMP-2 and-9 upregulation [44]. In agreement with these results, we found that AngII induced AKT phosphorylation in mammary epithelial cells at a very early time point $(1 \mathrm{~min})$. In contrast, Ang-(1-7) induced AKT phosphorilation at a later time point (15 $\mathrm{min})$. When both peptides were added together, the pattern of activation resembled that of $A n g(1-7)$ blunting the early effect of AngII. Moreover, to identify the receptors responsible for AngII and Ang-(1-7) mediated AKT phosphoryation, we used receptor-type-specific blockers. We found that AT1 and Mas receptor, were involved in AngII and Ang-(1-7)-mediated AKT phosphorylation, respectively. Furthermore, we could demonstrate in this study that AngII-induced EMT in non-tumorigenic mammary epithelial cell line NMuMG requires AKT activation.

Overexpression of AT1 in breast cancer cells induces EMT and promotes tumor growth and angiogenesis. AT1-overexpressing cells exhibited a mesenchymal-like phenotype, together with an increase in nuclear accumulation of phospho-Smad3 and Snail, increased Smad4 and N-cadherin levels, and a loss in E-cadherin [29]. Reduction in Smad4 has been shown to suppress TGF- $\beta$-induced responses associated with EMT in mammary epithelial NMuMG cells in vitro [50]. Furthermore, recent studies have reported that AT1 stimulation by AngII induces EMT via the Smad signaling pathway in renal epithelial cells and vascular smooth muscle cells in vitro [51, 52]. EMT is often associated with aggressive, invasive phenotypes and malignant tumor progression [42]. We show here for the first time that EMT induced by AngII in mammary epithelial cells is partially blocked by Ang-(1-7). Interestingly, the concomitant treatment with both angiotensin peptides, restored E-cadherin expression. This finding suggests that Ang-(1-7) promotes attachment of epithelial cells to the extracellular matrix becoming less prone to migrate.

Ang-(1-7) is a natural bioactive peptide of the reninangiotensin system produced in many tissues by ACE2 using AngII as a substrate. It has been shown that Ang-(1-7) reduces the growth of human lung tumor xenografts, with a concomitant decrease in VEGF and reduced vessel density, as well as decreasing the growth of orthotopic human estrogen receptor-positive or HER2-overexpressing breast tumor xenografts $[10,53,54]$. It has also been recently demonstrated that Ang-(1-7) decreases cell growth and angiogenesis of human nasopharyngeal carcinoma xenografts [55]. However, there are only very few reports on Ang-(1-7)'s role in breast cancer development. We demonstrate here that in a highly aggressive and metastatic breast cancer cell line Ang-(1-7) completely prevented AngII-induced cell migration and invasion.

Besides, our study shows that AngII-induced ERK1/2 activation is inhibited by Ang-(1-7). Several studies have shown that activation of ERK1/2 plays an important role in cell migration of several tumors [56]. Our studies are also in agreement with the previous studies demonstrating that Ang-(1-7) decreases the ERK1/2 signal transduction pathway in lung and prostate cancer $[14,53]$. It is likely that Ang-(1-7) activates a signaling pathway that negatively regulates AngII-induced ERK1/2 and AKT activation and through this mechanism is able to block breast cancer migration and invasion induced by AngII. Further studies unveiling the exact mechanism through which Ang-(1-7) counteracts AngII effects might help to provide a better understanding of their role in breast cancer development.

Enzymatic degradation of ECM is one of the crucial steps in cancer invasion and metastasis. MMP-9, is the main extracellular matrix protein-degrading enzyme known to play an important role in breast cancer cell migration and invasion $[57,58]$. In breast tumor D3H2LN cells, AngII upregulates MMP-2 / MMP-9 and ICAM1, which are involved in cell adhesion, migration, and invasion [59]. In MDA-MB-231 cells, specific blocking of MMP-2 and MMP-9 by siRNA significantly suppressed AngII-induced cell migration [24, 44]. In this study, we found that the enhanced expression and enzymatic activity of MMP-9 induced by AngII was significantly abolished by Ang-(1-7). Moreover, we also found that Ang-(1-7) in breast cancer cells also inhibits AngII-induced VEGF expression, a robust stimulator of angiogenesis. Notably, VEGF expression is required for the increased tumor initiation capacity of breast cancer cells that have undergone EMT [43]. These results are in agreement with 
previous studies showing significant VEGF reduction in nasopharyngeal carcinoma cell lines overexpressing Ang(1-7) [55]. As we also show in this study that anti-VEGF treatment of triple negative breast cancer cells completely suppresses AngII-induced migration, our results may also indicate the potency of a new strategy, using a combined treatment of Ang-(1-7) and anti- VEGF to prevent invasion, angiogenesis, and metastasis of aggressive breast cancer tumors.

The opposing biological effects of Ang-(1-7) and AngII in different scenarios has been vastly demonstrated [60]. However, whether Ang-(1-7) had any protective effect against breast cancer progression remained unknown. In the present study, we explored this possibility and we found that Ang-(1-7) reverses EMT, migration, invasion, VEGF, and MMP-9 activity induced by AngII. Consequently, in our experimental settings, activation of the Ang-(1-7)/ Mas receptor axis acts as a physiological antagonist of the AngII/AT1 receptor axis. Therefore, it is worth to evaluate in upcoming experiments, whether Ang(1-7) represents a better alternative to prevent breast cancer progression than the treatment with an AT1 receptor blocker.

\section{MATERIALS AND METHODS}

\section{Reagents and antibodies}

D-Ala - Ang-(1-7) (A779), Irbesartan, AngII and Ang-(1-7) were purchased from Bachem AG, Bubendorf, Switzerland, Losartan from Sigma-Aldrich (St. Louis, MO, USA), and PD123319 (PD) from Parke-Davis Pharmaceutical Research (Detroit, MI, USA). D-Pro ${ }^{7}$ Ang-(1-7) (D-Pro) was manufactured by Biosyntan (Berlin, Germany), the monoclonal anti-VEGF antibody, bevacizumab, was purchased from Roche, Switzerland), antibodies against AKT and pAKT from Cell Signaling (Beverly, CA, USA) and against ERK and pERK from Santa Cruz Biotechnology Inc. (Santa Cruz CA, USA.). The primary antibody for immunofluorescence, anti-Ecadherin/CDH1 (ECCD-2), was purchased from Zymed - Thermo Scientific (Massachusetts, USA), and antifibronectin from Gibco-BRL (Massachusetts, USA). The secondary antibodies for immunofluorescence, anti-rat Alexa Fluor 568 and anti-rabbit Alexa Fluor 488, came from Thermo - Scientific. The other secondary antibodies used including horseradish peroxidase (HRP)-conjugated antirabbit and mouse IgG have been delivered by Santa Cruz Biotechnology Inc. AKT inhibitor A6730 (Akt1/2 kinase inhibitor), phosphatase inhibitor, and protease inhibitor cocktail were purchased from Sigma. Oligos for qRT-PCR were acquired from Invitrogen (Carlsbad, CA, USA).

\section{Cell culture and treatments}

NMuMG cells were grown in Dulbecco's Modified Eagle's Medium (DMEM high glucose, Invitrogen
(Massachusetts, USA) supplementary with $10 \%$ fetal bovine serum; MDA-MB231 cells were grown in RPMI 1640 supplementary with $10 \%$ fetal bovine serum; and LM3 cells, derived from mammary adenocarcinoma spontaneously occuring in Balb/c mice, were gently provided by Dr. Elisa Bal de Kier Joffé, (Roffo Institute, Buenos Aires, Argentina) and grown in MEM supplementary with $5 \%$ fetal bovine serum. All cells were incubated at $37^{\circ} \mathrm{C}$ in a humidified atmosphere of $5 \% \mathrm{CO}_{2}$. For Wound Healing Migration assays, MDA-MB231 and LM3 cells were grown to confluence and then starved in serum-free medium during $8 \mathrm{~h}$ before being treated with AngII, Ang-(1-7), or both (10$\left.{ }^{7} \mathrm{M}\right)$. For transwell migration and invasion assays, cells were starved for 24 in medium supplemented with $1 \%$ serum and then incubated with AngII, Ang-(1-7) or both $10^{-6} \mathrm{M}$ in serum free medium. For CellTiter 96* Aqueous One Solution Cell Proliferation Assay (MTS), zymography, and MMP-9 and VEGF expression assays, the AngII/Ang-(1-7) concentration was $10^{-7} \mathrm{M}$. For Western blot (WB) assays, NMuMG cells were starved in serum-free medium for $3 \mathrm{~h}$, and then, cells were stimulated at different time points with AngII, Ang(1-7), or both at a final concentration of $10^{-7} \mathrm{M}$. When treated with AT1, AT2, and Mas receptor blockers, cells were preincubated for $5 \mathrm{~min}$ with the corresponding antagonists, at a final concentration of $10^{-6} \mathrm{M}$. For EMT assays, cells were starved over-night in 2\% serum-supplemented medium, and then treated with AngII, Ang-(1-7), or both in a concentration of $10^{-7} \mathrm{M}$, every $24 \mathrm{~h}$ for 3 days. Cells stimulated with TGF- $\beta$ ( $4 \mathrm{ng} / \mathrm{ml}$; positive control), received treatment every $48 \mathrm{~h}$ for 3 days. In assays in which the AKT inhibitor, A6730, was used, its final concentration was $1 \mu \mathrm{M}$, and cells were preincubated with it for $1 \mathrm{~h}$.

\section{Quantitative RT-PCR}

Quantitative Real-Time PCR was performed as previously described [61]. cDNA was synthesized from $1 \mu \mathrm{g}$ of total RNA using oligo-dT and reverse transcriptase (Reverse Transcriptase MMLV, Promega, Madison, USA) as recommended by the manufacturer. PCR amplification (35 cycles) was performed on $20 \mathrm{ng}$ cDNA using oligonucleotide primers as follows:

- Mouse E-cadherin forward GCTTCAGT TCCGAGGTCTACAC, reverse CTGTGATGGTGCC GTCTGTC;

- Mouse fibronectin forward TACCAAGG TCAATCCACACCCC, reverse CAGATGGCAA AAGAAAGCAGAGG;

- Mouse GAPDH forward GAGTCAACG GATTTGGTC, reverse CGAAGGTGGAAGAGTGG GAGTTG;

- Human GAPDH- forward GAGTCAACG GATTTGGTC, reverse TTGATTTTGGAGGGATCTCG;

- Mouse MMP9 forward AGACCTGGGCA GATTCCAAACC, reverse GCAAAGGCGTCG TCAATCACC; 
- Mouse N-cadherin forward TGGATGAAA CGGCGGGATAA, reverse TGTGGCTCAGCATG GATAGG;

- Mouse $\alpha$-SMA forward ACCACCATGT ACCCAGGCATT, reverse GCTGGAAGGT AGACAGCGAAG;

- Mouse VEGF-F forward GCCCACTGAG GAGTCCAACA, reverse GCTGGCCTTGGTGAGGTTT.

\section{Western blot analysis}

Cells were solubilized in lysis buffer $(30 \mathrm{mM} \mathrm{NaCl}$, $0.5 \%$ TritonX-100, $50 \mathrm{mM}$ Tris- $\mathrm{HCl}$; $\mathrm{pH} 7.4$ ) containing a cocktail of phosphatase and protease inhibitors. Supernatant was collected $\left(14,000 \times \mathrm{g}, 4^{\circ} \mathrm{C}, 20 \mathrm{~min}\right)$, and protein concentration was determined with a Bradford protein assay kit (Bio-Rad Laboratories, California, USA). Equal quantities of protein $(25 \mu \mathrm{g})$ were subjected to SDS-PAGE and transferred onto PVDF membranes (GE Healthcare Life Science, Buckinghamshire, UK). The membranes were incubated at $4{ }^{\circ} \mathrm{C}$ overnight with primary antibodies ERK1/2 (1:1,000), p-ERK1/2 (1:1,000), AKT $(1: 1,000)$, pAKT $(1: 1,000)$, GAPDH $(1: 1,000)$, diluted in $3 \%$ of dry low-fat milk or $3 \%$ BSA for phosphorylated antibodies, followed by incubation with horseradish peroxidase (HRP)-conjugated rabbit or mouse $\mathrm{IgG}$ $(1: 5,000)$. Signal intensity was detected using an Enhanced Chemiluminescence Kit (ECL Prime, Amersham, GE Healthcare, Buckinghamshire, England) and quantified using Syngene G-Box XR5 (Syngene, Maryland, USA).

\section{Zymography}

Conditioned medium from MDA-MB-231 cells, previously treated for $24 \mathrm{~h}$ with AngII, Ang-(1-7), or both in serum-free medium, were collected and centrifuged at $800 \mathrm{rpm}$ for $5 \mathrm{~min}$ to remove cellular debris. Samples were then subjected to electrophoresis on gelatin substrate gels (8.8\% SDS-polyacrylamide slab gels containing $1 \mathrm{mg} / \mathrm{ml}$ gelatin). MMP9 activity was visualized as a clear band at $90 \mathrm{kDa}$ after Coomassie Blue coloration. The zymograms were scanned and subjected to densitometric analyses using the PC version of NIH Image J (Scion Corp., Frederick, MD, USA).

\section{Immunofluorescence}

NMuMG cells were grown on sterile glass cover slips in 12-well plates for 4 days and immediately fixed with $4 \%$ Paraformaldehyde in PBS. After being washed $2 \mathrm{x}$ with PBS, they were incubated for 15 min with a PBS $+0.1 \%$ Triton $\mathrm{X}-100$ solution, and then blocked $1 \mathrm{~h}$ with $5 \%$ BSA in PBS + Triton X-100 0.025\% solution. Then, they were washed and incubated with the appropriate primary antibodies over-night at $4^{\circ} \mathrm{C}$ : anti E-cadherin $(1: 2,000)$ and anti-fibronectin $(1: 100)$ diluted in a $3 \%$
BSA/PBS-T solution, or vehicle as an isotype control. Cells were incubated with specific secondary antibodies: Alexa 568 conjugated goat ant-rat or Alexa 488 conjugated goat ant-rabbit, diluted (both 1:400) in 3\% BSA/PBS-T solution. Nuclei were counterstained with 4',6-diamidino2-fenylindole (DAPI; Sigma Aldrich, St. Louis, MO, USA) for $10 \mathrm{~min}$. Sections were finally air-dried and mounted with $80 \%$ glycerol. Immunofluorescence pictures were acquired with Olympus IX-81 fluorescence microscope (Tokyo, Japan). ImageJ was used for processing and analysis of the signal intensity.

\section{Migration Assays}

For wound healing assays with MDA-MB231 or LM3 cells, 500,000 cells were grown to confluence in 6-well plates and, after starvation, cross-shape wounds were performed in the monolayer using a sterile $10-\mu 1$ pipette tip. Wounds were scanned by phase contrast microscopy immediately after scratching (T0) and after $16 \mathrm{~h}$ in serum-free medium (T16) treated with AngII $\left(10^{-7} \mathrm{M}\right)$ and/or Ang-(1-7) $\left(10^{-7} \mathrm{M}\right)$ and or bevacizumab (100 ug/ml). For wound-closure area quantification, 3 images per wound were captured, in a total of 2 wounds per well, at T0 and T16, using a camera (Nikon Coolpix P5100; Tokyo, Japan) integrated to a white field inverted microscope (Nikon Eclipse TS100). The areas were quantified using Image Pro-Plus software (Media Cybernetics, Inc. Rockville, MD, USA). For each condition, the wound closure was calculated as the ratio of wound diameter at $\mathrm{T} 16$ relative to $\mathrm{T} 0$.

For transwell migration assays, cell motility was tested in $8-\mu \mathrm{m}$ pore polycarbonate membrane transwell chambers (Corning Inc, NY, USA). Membranes were coated on both sides with $25 \mu \mathrm{g} / \mathrm{ml}$ of rat tail collagen I (Roche, Basel, Switzerland). Cells were starved in medium ( $1 \%$ serum) for $24 \mathrm{~h}$. For plating in transwells, cells were re-suspended in serum-free medium and 80,000 cells $/ 250 \mu \mathrm{l}$ were added to the top chamber, with the corresponding angiotensin or PBS as negative control. Five hundred $\mu 1$ serum-free medium was added to the bottom chamber, except for one which contained $10 \%$ serum as a positive control of migration. Cells were allowed to migrate for $20 \mathrm{~h}$. For quantification, non-migrated cells were scraped from the top membrane, and migrated cells in the lower chamber were fixed in fresh 4\% PFA for $20 \mathrm{~min}$ and stained in $0.1 \%$ crystal violet for $30 \mathrm{~min}$. Once washed with $\mathrm{H}_{2} \mathrm{O}$ and air dried, pictures were taken, and migrated cells were counted in five different random fields in duplicate wells using a camera integrated to a white field inverted microscope. The number of cells/ field was counted using the Image $1.37 \mathrm{v}$ software, and results were expressed as the number of treated cells capable to migrate per field. The results were expressed showing the mean \pm SEM. 


\section{Invasion Assay}

Invasion was tested in $8-\mu \mathrm{m}$ pore polycarbonate membrane transwell chambers coated with matrigel matrix $0.3 \mathrm{mg} / \mathrm{ml}$ (Corning, NY, USA) according to the manufacturer's recommendations. For plating in transwells, cells were re-suspended in serum-free medium, and $1.5 \times 10^{5}$ cells $/ 250 \mu \mathrm{l}$ were added to the top chamber with the corresponding angiotensin or PBS as a negative control. Five hundred $\mu \mathrm{l}$ serum-free medium was added to the bottom chamber, except for one well which contained $10 \%$ serum as a positive control of invasion. Cells were allowed to migrate for $24 \mathrm{~h}$ and then proceeded following the transwell migration assayed describe above.

\section{Cell viability assay}

Cell viability was assessed using the CellTiter 96* Aqueous One Solution Cell Proliferation Assay [MTS, 3-(4,5-dimethylthiazol-2yl)-5-(3-carboxymethoxyphenyl)2-(4-sulfophenyl)-2H-tetrazolium] (Promega, Madison, WI, USA). Three thousand MDA-MB231 cells were grown in a 96-well plate and starved in medium containing $2 \%$ FBS. After $24 \mathrm{~h}$, cells were stimulated with AngII, Ang-(1-7) or both $\left(10^{-7} \mathrm{M}\right)$ in serum-free medium. The cell proliferation assay was then performed according to the manufacturer's instructions. The quantity of formazan product was determined by measuring absorbance at $450 \mathrm{~nm}$ using a microplate sepectophotometer (Glomax Multi Detection System, Promega, WI, USA).

\section{Statistical Analysis}

Statistical significance of differences was determined with One-way ANOVA followed by Tukey posttest. Data are as mean \pm SEM. A $P$ value of less than 0.05 was considered statistically significant.

\section{ACKNOWLEDGMENTS}

This work was supported by research grants awarded to C.S.L: from ANPCyT (PICT 2011-1638), PIPCONICET and National Cancer Institute (INC) 2016; to T.W. and C.S.L. from MINCYT-DAAD (DA1203), and to T.W. from the Deutsche Forschungsgemeinschaft (WA 1441/22-2).

\section{CONFLICTS OF INTEREST}

The authors declare there are no conflicts of interest.

\section{REFERENCES}

1. Sadoshima J. Cytokine actions of angiotensin II. Circ Res. 2000; 86: 1187-9. https://doi.org/10.1161/01.RES.86.12.1187.
2. Phillips MI, Kagiyama S. Angiotensin II as a proinflammatory mediator. Curr Opin Investig Drugs. 2002; 3 : 569-77.

3. Diep QN, El MM, Touyz RM, Schiffrin EL. Expression of cell cycle proteins in blood vessels of angiotensin II-infused rats: role of AT(1) receptors. Hypertension. 2001; 37: 604-8.

4. Clauser E, Curnow KM, Davies E, Conchon S, Teutsch B, Vianello B, Monnot C, Corvol P. Angiotensin II receptors: protein and gene structures, expression and potential pathological involvements. Eur J Endocrinol. 1996; 134: 403-11.

5. Unger $\mathrm{T}$. The role of the renin-angiotensin system in the development of cardiovascular disease. Am J Cardiol. 2002; 89: 3A-9A.

6. Romero CA, Orias M, Weir MR. Novel RAAS agonists and antagonists: clinical applications and controversies. Nat Rev Endocrinol. 2015; 11: 242-52. https://doi.org/10.1038/ nrendo.2015.6.

7. Mercure C, Yogi A, Callera GE, Aranha AB, Bader M, Ferreira AJ, Santos RAS, Walther T, Touyz RM, Reudelhuber TL. Angiotensin(1-7) blunts hypertensive cardiac remodeling by a direct effect on the heart. Circ Res. 2008; 103: 1319-26. https://doi.org/10.1161/ CIRCRESAHA.108.184911.

8. Rabelo LA, Alenina N, Bader M. ACE2-angiotensin-(17)-Mas axis and oxidative stress in cardiovascular disease. Hypertens Res. 2011; 34: 154-60. https://doi.org/10.1038/ hr.2010.235.

9. Santos RA. Angiotensin-(1-7). Hypertens (Dallas, Tex 1979). 2014; 63: 1138-47. https://doi.org/10.1161/ HYPERTENSIONAHA.113.01274.

10. Menon J, Soto-Pantoja DR, Callahan MF, Cline JM, Ferrario CM, Tallant EA, Gallagher PE. Angiotensin-(1-7) inhibits growth of human lung adenocarcinoma xenografts in nude mice through a reduction in cyclooxygenase-2. Cancer Res. 2007; 67: 2809-15. https://doi.org/10.1158/0008-5472. CAN-06-3614.

11. Ferrario CM, Chappell MC, Dean RH, Iyer SN. Novel angiotensin peptides regulate blood pressure, endothelial function, and natriuresis. J Am Soc Nephrol. 1998; 9: 1716-22.

12. Santos RA, Campagnole-Santos MJ, Andrade SP. Angiotensin-(1-7): an update. Regul Pept. 2000; 91: 45-62.

13. Tallant EA, Diz DI, Ferrario CM. State-of-the-Art lecture. Antiproliferative actions of angiotensin-(1-7) in vascular smooth muscle. Hypertens (Dallas, Tex 1979). 1999; 34: 950-7.

14. Krishnan B, Torti FM, Gallagher PE, Tallant EA. Angiotensin-(1-7) reduces proliferation and angiogenesis of human prostate cancer xenografts with a decrease in angiogenic factors and an increase in sFlt-1. Prostate. 2013; 73: 60-70. https://doi.org/10.1002/pros.22540.

15. Santos RA, Simoes e Silva AC, Maric C, Silva DM, Machado RP, de Buhr I, Heringer-Walther S, Pinheiro SV, Lopes MT, Bader M, Mendes EP, Lemos VS, 
Campagnole-Santos MJ, et al. Angiotensin-(1-7) is an endogenous ligand for the $\mathrm{G}$ protein-coupled receptor Mas. Proc Natl Acad Sci U S A. 2003; 100: 8258-63. https://doi. org/10.1073/pnas.1432869100.

16. Paul M, Poyan Mehr A, Kreutz R. Physiology of local renin-angiotensin systems. Physiol Rev. 2006; 86: 747-803. https://doi.org/10.1152/physrev.00036.2005.

17. Inwang ER, Puddefoot JR, Brown CL, Goode AW, Marsigliante S, Ho MM, Payne JG, Vinson GP. Angiotensin II type 1 receptor expression in human breast tissues. Br J Cancer. 1997; 75: 1279-83.

18. Tahmasebi M, Barker S, Puddefoot JR, Vinson GP. Localisation of renin-angiotensin system (RAS) components in breast. Br J Cancer. 2006; 95: 67-74. https:// doi.org/10.1038/sj.bjc.6603213.

19. De Paepe B, Verstraeten VL, De Potter CR, Vakaet LA, Bullock GR. Growth stimulatory angiotensin II type-1 receptor is upregulated in breast hyperplasia and in situ carcinoma but not in invasive carcinoma. Histochem Cell Biol. 2001; 116: 247-54. https://doi.org/10.1007/s004180100313.

20. Nahmod KA, Walther T, Cambados N, Fernandez N, Meiss R, Tappenbeck N, Wang Y, Raffo D, Simian M, Schwiebs A, Pozner RG, Fuxman Bass JI, Pozzi AG, et al. AT1 receptor blockade delays postlactational mammary gland involution: a novel role for the renin angiotensin system. FASEB J. 2012; 26: 1982-94. https://doi.org/10.1096/fj.11-191932.

21. Greco S, Muscella A, Elia MG, Salvatore P, Storelli C, Mazzotta A, Manca C, Marsigliante S. Angiotensin II activates extracellular signal regulated kinases via protein kinase $\mathrm{C}$ and epidermal growth factor receptor in breast cancer cells. J Cell Physiol. 2003; 196: 370-7. https://doi.org/10.1002/jcp.10313.

22. Walther T, Menrad A, Orzechowski HD, Siemeister G, Paul M, Schirner M. Differential regulation of in vivo angiogenesis by angiotensin II receptors. FASEB J. 2003; 17: 2061-7. https://doi.org/10.1096/fj.03-0129com.

23. Chen X, Meng Q, Zhao Y, Liu M, Li D, Yang Y, Sun L, Sui G, Cai L, Dong X. Angiotensin II type 1 receptor antagonists inhibit cell proliferation and angiogenesis in breast cancer. Cancer Lett. 2013; 328: 318-24. https://doi. org/10.1016/j.canlet.2012.10.006.

24. Rodrigues-Ferreira S, Abdelkarim M, Dillenburg-Pilla P, Luissint AC, di-Tommaso A, Deshayes F, Pontes CL, Molina A, Cagnard N, Letourneur F, Morel M, Reis RI, Casarini DE, et al. Angiotensin II facilitates breast cancer cell migration and metastasis. PLoS One. 2012; 7: e35667. https://doi.org/10.1371/journal.pone.0035667.

25. Luo Y, Ohmori H, Shimomoto T, Fujii K, Sasahira T, Chihara Y, Kuniyasu H. Anti-angiotensin and hypoglycemic treatments suppress liver metastasis of colon cancer cells. Pathobiology. 2011; 78: 285-90. https://doi. org/10.1159/000330169.

26. Domińska K, Piastowska-Ciesielska AW, LachowiczOchędalska A, Ochędalski T. Similarities and differences between effects of angiotensin III and angiotensin II on human prostate cancer cell migration and proliferation. Peptides. 2012; 37: 200-6. https://doi.org/10.1016/j.peptides.2012.07.022.

27. Zhao Y, Chen X, Cai L, Yang Y, Sui G, Wu J. Angiotensin II suppresses adriamycin-induced apoptosis through activation of phosphatidylinositol 3-kinase/Akt signaling in human breast cancer cells. Acta Biochim Biophys Sin (Shanghai). 2008; 40: 304-10.

28. Zhao Y, Chen X, Cai L, Yang Y, Sui G, Fu S. Angiotensin II/ angiotensin II type I receptor (AT1R) signaling promotes MCF-7 breast cancer cells survival via PI3-kinase/Akt pathway. J Cell Physiol. 2010; 225: 168-73. https://doi.org/10.1002/jcp.22209.

29. Oh E, Kim JY, Cho Y, An H, Lee N, Jo H, Ban C, Seo JH. Overexpression of angiotensin II type 1 receptor in breast cancer cells induces epithelial-mesenchymal transition and promotes tumor growth and angiogenesis. Biochim Biophys Acta. 2016; 1863: 1071-81. https://doi.org/10.1016/j. bbamcr.2016.03.010.

30. Nieto MA, Huang RY, Jackson RA, Thiery JP. EMT: 2016. Cell. 2016; 166: 21-45. https://doi.org/10.1016/j. cell.2016.06.028.

31. Deshayes F, Nahmias C. Angiotensin receptors: a new role in cancer? Trends Endocrinol Metab. 2005; 16: 293-9. https://doi.org/10.1016/j.tem.2005.07.009.

32. George AJ, Thomas WG, Hannan RD. The reninangiotensin system and cancer: old dog, new tricks. Nat Rev Cancer. 2010; 10: 745-59. https://doi.org/10.1038/nrc2945.

33. Miyajima A, Kosaka T, Asano T, Asano T, Seta K, Kawai T, Hayakawa M. Angiotensin II type I antagonist prevents pulmonary metastasis of murine renal cancer by inhibiting tumor angiogenesis. Cancer Res. 2002; 62: 4176-9.

34. Fujita M, Hayashi I, Yamashina S, Itoman M, Majima M. Blockade of angiotensin AT1a receptor signaling reduces tumor growth, angiogenesis, and metastasis. Biochem Biophys Res Commun. 2002; 294: 441-7. https://doi. org/10.1016/S0006-291X(02)00496-5.

35. Takahashi T, Taniguchi T, Konishi H, Kikkawa U, Ishikawa Y, Yokoyama M. Activation of Akt/protein kinase B after stimulation with angiotensin II in vascular smooth muscle cells. Am J Physiol. 1999; 276: H1927-34.

36. Tetzner A, Gebolys K, Meinert C, Klein S, Uhlich A, Trebicka J, Villacañas Ó, Walther T. G-Protein-Coupled Receptor MrgD Is a Receptor for Angiotensin-(1-7) Involving Adenylyl Cyclase, cAMP, and Phosphokinase A. Hypertens (Dallas, Tex 1979). 2016; 68: 185-94. https://doi. org/10.1161/HYPERTENSIONAHA.116.07572.

37. Klein N, Gembardt F, Supé S, Kaestle SM, Nickles H, Erfinanda L, Lei X, Yin J, Wang L, Mertens M, Szaszi K, Walther T, Kuebler WM. Angiotensin-(1-7) protects from experimental acute lung injury. Crit Care Med. 2013; 41: e334-43. https://doi.org/10.1097/CCM.0b013e31828a6688.

38. Lotz-Jenne C, Lüthi U, Ackerknecht S, Lehembre F, Fink T, Stritt M, Wirth M, Pavan S, Bill R, Regenass U, Christofori 
G, Meyer-Schaller N. A high-content EMT screen identifies multiple receptor tyrosine kinase inhibitors with activity on TGF $\beta$ receptor. Oncotarget. 2016; 7: 25983-6002. https:// doi.org/10.18632/oncotarget.8418.

39. Klymkowsky MW, Savagner P. Epithelial-mesenchymal transition: a cancer researcher's conceptual friend and foe. Am J Pathol. 2009; 174: 1588-93. https://doi.org/10.2353/ ajpath.2009.080545.

40. Heldin $\mathrm{CH}$, Vanlandewijck M, Moustakas A. Regulation of EMT by TGF $\beta$ in cancer. FEBS Lett. 2012; 586: 1959-70. https://doi.org/10.1016/j.febslet.2012.02.037.

41. Wu Y, Sarkissyan M, Vadgama JV. Epithelial-Mesenchymal Transition and Breast Cancer. J Clin Med. 2016; 5. https:// doi.org/10.3390/jcm5020013.

42. Kalluri R, Weinberg RA. The basics of epithelialmesenchymal transition. J Clin Invest. 2009; 119: 1420-8. https://doi.org/10.1172/JCI39104.

43. Fantozzi A, Gruber DC, Pisarsky L, Heck C, Kunita A, Yilmaz M, Meyer-Schaller N, Cornille K, Hopfer U, Bentires-Alj M, Christofori G. VEGF-mediated angiogenesis links EMT-induced cancer stemness to tumor initiation. Cancer Res. 2014; 74: 1566-75. https://doi. org/10.1158/0008-5472.CAN-13-1641.

44. Zhao Y, Wang H, Li X, Cao M, Lu H, Meng Q, Pang H, Li H, Nadolny C, Dong X, Cai L. Ang II-AT1R increases cell migration through PI3K/AKT and NF- $\kappa$ B pathways in breast cancer. J Cell Physiol. 2014; 229: 1855-62. https:// doi.org/10.1002/jcp.24639.

45. Egami K, Murohara T, Shimada T, Sasaki KI, Shintani S, Sugaya T, Ishii M, Akagi T, Ikeda H, Matsuishi T, Imaizumi T. Role of host angiotensin II type 1 receptor in tumor angiogenesis and growth. J Clin Invest. 2003; 112: 67-75. https://doi.org/10.1172/JCI16645.

46. Imai N, Hashimoto T, Kihara M, Yoshida S, Kawana I, Yazawa T, Kitamura H, Umemura S. Roles for host and tumor angiotensin II type 1 receptor in tumor growth and tumor-associated angiogenesis. Lab Invest. 2007; 87: 18998. https://doi.org/10.1038/labinvest.3700504.

47. Müller A, Homey B, Soto H, Ge N, Catron D, Buchanan ME, McClanahan T, Murphy E, Yuan W, Wagner SN, Barrera JL, Mohar A, Verástegui E, et al. Involvement of chemokine receptors in breast cancer metastasis. Nature. 2001; 410: 50-6. https://doi.org/10.1038/35065016.

48. Ye Y, Tang X, Sun Z, Chen S. Upregulated WDR26 serves as a scaffold to coordinate $\mathrm{PI} 3 \mathrm{~K} / \mathrm{AKT}$ pathway-driven breast cancer cell growth, migration, and invasion. Oncotarget. 2016; 7: 17854-69. https://doi.org/10.18632/oncotarget.7439.

49. Ishimatsu S, Itakura A, Okada M, Kotani T, Iwase A, Kajiyama H, Ino K, Kikkawa F. Angiotensin II augmented migration and invasion of choriocarcinoma cells involves PI3K activation through the AT1 receptor. Placenta. 2006; 27: 587-91. https://doi.org/10.1016/j.placenta.2005.07.001.

50. Deckers M, van Dinther M, Buijs J, Que I, Löwik C, van der Pluijm G, ten Dijke P. The tumor suppressor Smad4 is required for transforming growth factor beta-induced epithelial to mesenchymal transition and bone metastasis of breast cancer cells. Cancer Res. 2006; 66: 2202-9. https:// doi.org/10.1158/0008-5472.CAN-05-3560.

51. Yang F, Huang XR, Chung AC, Hou CC, Lai KN, Lan HY. Essential role for Smad3 in angiotensin II-induced tubular epithelial-mesenchymal transition. J Pathol. 2010; 221: 390-401. https://doi.org/10.1002/path.2721.

52. Carvajal G, Rodríguez-Vita J, Rodrigues-Díez R, SánchezLópez E, Rupérez M, Cartier C, Esteban V, Ortiz A, Egido J, Mezzano SA, Ruiz-Ortega M. Angiotensin II activates the Smad pathway during epithelial mesenchymal transdifferentiation. Kidney Int. 2008; 74: 585-95. https:// doi.org/10.1038/ki.2008.213.

53. Gallagher PE, Tallant EA. Inhibition of human lung cancer cell growth by angiotensin-(1-7). Carcinogenesis. 2004; 25 : 2045-52. https://doi.org/10.1093/carcin/bgh236.

54. Cook KL, Metheny-Barlow LJ, Tallant EA, Gallagher PE. Angiotensin-(1-7) reduces fibrosis in orthotopic breast tumors. Cancer Res. 2010; 70: 8319-28. https://doi. org/10.1158/0008-5472.CAN-10-1136.

55. Pei N, Wan R, Chen X, Li A, Zhang Y, Li J, Du H, Chen B, Wei W, Qi Y, Zhang Y, Katovich MJ, Sumners C, et al. Angiotensin-(1-7) Decreases Cell Growth and Angiogenesis of Human Nasopharyngeal Carcinoma Xenografts. Mol Cancer Ther. 2016; 15: 37-47. https://doi.org/10.1158/15357163.MCT-14-0981.

56. Katz M, Amit I, Yarden Y. Regulation of MAPKs by growth factors and receptor tyrosine kinases. Biochim Biophys Acta. 2007; 1773: 1161-76. https://doi.org/10.1016/j. bbamcr.2007.01.002.

57. Galis ZS, Johnson C, Godin D, Magid R, Shipley JM, Senior RM, Ivan E. Targeted disruption of the matrix metalloproteinase-9 gene impairs smooth muscle cell migration and geometrical arterial remodeling. Circ Res. 2002; 91: 852-9.

58. Zhang F, Hu Y, Xu Q, Ye S. Different effects of angiotensin II and angiotensin-(1-7) on vascular smooth muscle cell proliferation and migration. PLoS One. 2010; 5: e12323. https://doi.org/10.1371/journal.pone.0012323.

59. Castaneda CA, Cortes-Funes H, Gomez HL, Ciruelos EM. The phosphatidyl inositol 3-kinase/AKT signaling pathway in breast cancer. Cancer Metastasis Rev. 2010; 29: 751-9. https://doi.org/10.1007/s10555-010-9261-0.

60. Murugan D, Lau YS, Lau CW, Mustafa MR, Huang Y. Correction: Angiotensin 1-7 Protects against Angiotensin II-Induced Endoplasmic Reticulum Stress and Endothelial Dysfunction via Mas Receptor. PLoS One. 2016; 11: e0147892. https://doi.org/10.1371/journal.pone.0147892.

61. Levy CS, Slomiansky V, Gattelli A, Nahmod K, Pelisch F, Blaustein M, Srebrow A, Coso OA, Kordon EC. Tumor necrosis factor alpha induces LIF expression through ERK1/2 activation in mammary epithelial cells. J Cell Biochem. 2010; 110: 857-65. 